\title{
THE PHILOSOPHICAL PLATFORM OF THE ARCHITECT. WHY PHILOSOPHERS MAKE SUCH GOOD DRAWINGS?
}

\author{
A B S T R A C T
}

Theoretical interpretations and attempts at instrumentalisation of the ties and exchanges between philosophy and architecture have mostly been directed at questions of language or the institutionalisation of the discipline of architecture. In this text, I suggest a different approach to philosophical engagement in architecture: a simultaneous use in the methodology of the architectural project and constitution of a philosophy of architecture, not only as a question of interdisciplinary exchange, but as an integral part of comprehensive architectural processes, with philosophy still maintaining its original authenticity. My approach is twofold: explain the methodology and delineate its framework, but also raise the question what is an architect's philosophical platform. To that end, I will attempt to elaborate three models: 1) the first delves partially into the fields of fiction and illusion, and in it the architect adopts the role (position) of the philosopher, 2) the second model is the architectural engagement of philosophical notions, and 3) the third is the use of philosophical concepts in the creation of architectural ones. Corresponding to each, I will suggest the activity of "repetition of difference" as a possibility of creation of the authentic architectural concept.

\section{SnežanaVesnić}




\section{INTRODUCTION}

To the bipartite title, we should add two asymmetrical remarks about how to read this text. The first refers to my intention of taking my position of equal parts of architect, theorist, and practitioner to thematise the complicated relation between architecture and philosophy. The complications are endless, there are myriad of questions of interdisciplinary exchange, authenticity as well as the question of production - all of which is constantly redefining this relation. However, beyond all questions, my premise is that architecture, analogously to philosophy, as Deleuze and Guattari proposed in What Is Philosophy? is the creation of concepts. ${ }^{1}$ More specifically, architecture as well as philosophy is " $(\ldots)$ the art of the forming, inventing, and fabricating concepts." $[$ [“( $(.)$. la philosophie est l'art de former, d'inventer, de fabriquer des concepts."] To this sentence fragment, I add that all three verbs used (forming, inventing, fabricating) explicitly indicate the creation of the new. Thus, the first comment creates a specific environment in which the projection of the premise is read as a question: how to create concepts? The second remark holds a partial answer to the previous question. It is bound to the second part of the title and also speaks to the method of the text itself as well as (partially) to the elaboration of the method the text suggests. That is to say, what I wish to show is that the architectural use of philosophy, by which I mean philosophical concepts, is in the first instance similar to 'work' or an activity that is more similar to the conception of 'emancipation' of difference I find in Deleuze's concept of "difference and repetition." "What follows is a matter of pure "difference" or "difference repetition" or the potential of difference. This "difference" or the particular can become authentic material, the potential for creation or even for further architectural production.

\section{THE PYRAMID AND THE DREAM:}

\section{BETWEEN DISAPPEARANCE AND DEMATERIALISATION \\ OF THE ARCHITECTURAL SUBJECT}

Despite all the great relations interpreted by philosophy, the relation that has marked it as a whole, according to Theodor Adorno, is that of subject-object. This relation has traced its contemporary flow, so that it has become "the only philosophy: the philosophy of the subject." Adorno resolves the central problem of philosophy, the question of coexistence of the subject and object, in favour of the subject, finding confidence in the subject as opposed to the object. Subject-object, the co-dependent (non-)homogeneous pair is one of the essential constitutive blocks of philosophy, but also of architecture, and as a definition, it will always hold this complex relation together. Architecture has always been created and built within as a part of this relation. However asymmetrical it might 
have been, it has always thematised the subject of architecture as an 'author' of the architectural (ideal) object. Yet, with "What Is an Author?", Foucault suggested the idea of the literal disappearance (death) of the author. ${ }^{6}$ The subjectivity of the author ${ }^{7}$ can always be demonstrated through the objectivity of their creation. ${ }^{8}$ The subject of architecture exists by way of their creation; but paradoxically, by ensuring the autonomy to their object, that is, in the act of materialisation, the subject proves their own 'objective' disappearance. This is the process of cleaving of subject from their object. Hence, the relation and proximity of subject-object in architecture are complete only in the process of creation. In a way, Foucault has substituted the author with the trace of his absence, simultaneously abolishing his individuality. If we placed Foucault's disappearance of the author in the same plane with Adorno's fundamental subject-object relation, in the very next instance, the disappearance of the author (the subject) opens the question of lacuna in the place of the subject.

I would now like to sketch a few ways of 'disappearance of author', resisting Foucault's thesis of the death of the author. Indicating various techniques of authorial presence and absence, my aim is to explain temporary positions of the subject of architecture, that is, the functional change of the architect 'into' a philosopher, maintaining the object as the point of reference. These directions of modification of the subject of architecture are entirely in accordance with Baudrillard's definition of the disappearing as an art form, "art of disappearance." Following Baudrillard, the real world starts to exist, paradoxically, with its simultaneous "disappearance." Or, when things begin to disappear, the concept emerges: "the real vanishes into the concept." 10 These sentences provide me with the foothold for disappearance always generating "a" creation, and for expecting these processes to create a new concept, the concept of the subject or concept of the object. By way of this understanding of the art of disappearance, we can explain the beginning of the existence of the subject of architecture in some new (philosophical) reality. More simply, this is the self-conceptualisation of the architect with the goal of redefining the authorial potential to create. Further, the position in between theory and practice means that the subject of architecture always alternates between gesture and process, spurring the two forms Greg Lynn calls "(...) the author that makes the gesture, but (...) the author that makes the process." ${ }^{11}$ Whether the idea of the contemporary author in architecture is a question of a "new kind of author before the digital" 12 or very different interests for abstract forms of the subjectivity of the architect, somewhere between the designer and theorist - does not seem to be crucial. The potential for change and possibility of self-transformation of the architect, as Eisenman himself confirms, are legitimate ways of conceptualisation in architecture. Cyclical transgressions 
of the architect into other neighbouring areas as the expression of the will and desire for radical change of context and perspective of thought are only some of the models of the "disappearance of the author." Eisenman elaborates an example of such transgression in the particularity transformation of Corbusier's person: "(...) he was able to produce transfiguration out of figure in the work. In other words, not literal transfiguration but the conceptual idea of figure..."13 The processes of transfiguration that assume self-abstraction do not also mean the reduction or removal of the figure of the architect. For me, this is the kind of abstraction that Deleuze formulates as "an invention of other spaces with original sorts of mixture or assemblage prodigious," 14 or revealing and occupying new inspirational and 'other' territories. Thus, through alternating positions and experimentation with various media, Corbusier transformed his own architectural role. ${ }^{15}$ What is important, however, in all acts and projects, from macro-urban project such as plans for the city of Paris to the aesthetic acts of text and image in The Poem of the Right Angle (Le Poème de l'Angle Droit), ${ }^{16}$ in any architectural gesture, we can see the authentic 'traces of absence' of the author. If we look more closely at these processes, we can see that with a decision or intuition of transformation, whether done analytically through science, instinctively through language or drawing, or through the implementation and introduction of (virtual) technology, it is always a matter of architectural necessity for conceptualisation and mastery over reality. This is the moment when architects adopt another philosophical reality in order to assume a critical position towards their own. Aside from intuitive transformation, the precision of philosophy undoubtedly forces us towards taking one step further, to the question of notion, concept, and language. Perhaps it is only a matter of processes in order to present and explain things to ourselves, to name them and create the possibility of conceptualising and using them. Or else it is a change of dimension for the acceleration of time in order to reach our architectural object more quickly. Again, returning to Baudrillard's thesis that the concept appears with disappearance, simultaneously return to architectural reality by eliminating what has already appeared.

I see such a radical and specific model of "self-conceptualisation" of the architect in the complex work of Peter Eisenman. Among the many interpretations of this historic figure in architecture, Jörg Gleiter's interpretation, refracted in a single sentence, is perhaps the best testament to its radical nature: "How to eliminate what one becomes - this is one way of summarising one of the most decisive features of Eisenman's architectural praxis: the disappearance of the author."17 Recalling Barthes' text, "Death of the Author,"18 and Eisenman's drawing on Foucault's What Is an Author?, Gleiter's gestures paint an author who, for the sake of functionality of discipline, submits his own (authorial) 
function to critical operativeness. This is no mere discursive decomposition of the author or annihilation of the relation between architect and his work. It is a translation of the author's capacities into the contingency of critical approach to the discipline and the architectural definition of the world. Thus, toward the question "what is an author?", Gleiter projects the question, "what is critique?", (once again an echo of Foucault ${ }^{19}$ ) in order to explain the "elimination of the author." It is clear that for the sake of the "meta' plan (or project), ${ }^{20}$ the (ex) change of Eisenman's work and specific architectural critique will rest more heavily on the latter. However, perhaps here we could allow ourselves the freedom of a third question, which neither Foucault nor Eisenman poses: "what is (an architectural) creation?" In so doing, following the trace of absence of the personal of the created, ${ }^{21}$ perhaps we could understand the basic relation between the architect and philosopher. This is not an abstraction of an architect in the 'body' of the philosopher, but rather an idea of a relation of two subjects, a philosopher and an architect, mutually defined. The tensions and states of absence (of the object) equalise theoretical and practical action of the subjects, allowing for the appearance of those processes that define experience in which 'one' subject forms and alters the 'other'.

The need of the architect for abandoning their fundamental 'territory' is the necessity of the continuous redefinition of the relations within their work. Yet, perhaps more significantly, it is a possibility for the activation of creative critical abilities to produce, both theoretically and practically. Architecture is first and above all about the production of concepts, which is why the dislocation or temporary transfiguration of the architect into the "body of the philosopher," a natural architectural occurrence. The whole idea of necessary 'fleeing' towards one's otherness, towards a different geography or philosophy, is the architect's search for a new, original position and definition of meta-territory. For Jean Nouvel, all actions and strategies in architecture have as their aim to define an unknown location as the "locus of a secret." 22 In the relation between the idea, concept, and project, there is the architectural decision of what we wish to control, what to provoke, but also, what we willingly cede to the uncontrollable. ${ }^{23}$ But what is important architecturally, in all these actions, is the 'establishing' of the object in space and time simultaneously with the dematerialisation of the architectural subject. Paradoxically, dematerialisation indicates existence, while disappearance points to absence. The 'dematerialisation' of the architect in the process of design is equal to the existence of the subject through the inevitable motions using at once dislocation and distortion, just how Sloterdijk described the case of the figure of Derrida. The principle of dislocation establishes an interruption with "full presence," with spatial displacement and redisposition. The double meaning of 'distortion' that Sloterdijk borrowed from Freud ${ }^{24}$ indicates 
two kinds of change: in appearance, but also as a possibility for something (or someone) to be taken to be elsewhere. ${ }^{25}$ Here we arrive to the critical dimension of the author of architectural works. The subject of architecture is never fully and permanently free; they-subject-author always belongs to a given context by way of their object. This attempt at making a terminological (but no less strategic) distinction in the appearance of the subject, in order for it not to come second (like Freud's distortion), to change position through spatial displacement and redisposition, seems very important to me because it introduces different forms of self-conceptualisation of the architect. In that sense, Sloterdijk's thematisations give a complex insight into other ways of dematerialisation, while also indicating a shift from the question of production of object to context and location of author with regard to meta-territory. Within these horizons, there is a radical revelation regarding the meaning of the author, including the risk of assigning to their text (object) lesser value than to the broader context to which their words (or object) belong and in which they are reflected. The subject's temporarily-found freedom through displacement and appearance elsewhere will allow for achieving the complete creative engagement of the architect. Besides that, a complete change of context becomes an architectural strategy for the author to once again appear in an entirely different way in a different form or formation within their own discourse. The phenomenon of architectural fear of belonging and limitation in time is explained by an essential creative impotence that comes with the finitude itself. Therefore, the principle of disappearance andor dematerialisation, such as the 'first' contingency of the architectural subject, can be seen in the metaphor of 'pyramid'. With its mythological potential, it offers an idea of the Other. Architectural disappearance produces a new reality, like the concept that disappears in the real, meaning that the 'dream' as creation, the arrival and appearance, or else, as the 'second' contingency, a metaphor of the phenomenology of architectural aesthetic gesture of the role, the character, figure, engagement. With their complete removal from this discourse and their own practice, the architect temporarily adopts the philosopher's role to allow for new creation through the act of return.

\section{WORDS AND OBJECTS OF THE AUTHOR}

Any form of production in architecture is necessarily an activity or gesture of representation of presence. Objects in architecture, material or not, always reflect the meaning that seek its own word, expression, or manifesto. However, if we are still resting on the notion that architecture, analogously to philosophy, is the creation of concepts, then architecture also produces with words. Derrida saw the potential for creation in words, a capacity to produce, to construct, but also the possibility to recognise potential places to destabilise 
(the French) language. Indeed, this was the interest in "the body of the word" that "is not present to itself," and moments when words slip from their original discourse by acquiring new functions. ${ }^{26}$ In these cases, flouting their basic function, words become what essentially does not belong to language, become the capacity for something Other. The production of ambivalent states that can be achieved through words hints at the existence of the idea that action is possible within text and with text. Speaking architecturally, it is true that words enable or offer that which is not 'now' or that which is not yet real or that which has not yet been actualised through the object's presence. Every architectural object begins its existence with a concept, confirming its presence of reflections of concepts in words, even when the concept is not entirely materialised. Eisenman has placed 'language' as the inevitable mediator and participant in the act of transfer of architectural meaning, nearly to the point of equalising it with the architecturally materialised object. He interprets the final metaphysics of architecture as object-text, whose entirety and completeness is established in a superposed state of presence and presence absence. ${ }^{27}$ By indirectly deconstructing the role of the architect through conceptualising Eisenman's work, Derrida asked a very important question: "What are words for an architect?"28 Beyond all the physical and metaphysical uses of words in architecture, the value of words can be simply found in what Derrida called "the body of the word:" 29 even when non-discursive, a word that could use the ability to avoid form in order to create, can be used discursively. In that sense, terms borrowed from philosophy (as the "body of the word") become a resource for architecture, entities, sequences, signs or particles - instruments (and not mere media) for the fashioning of devices and structures of the architectural conceptual system. We have here the creation of a framework with a high degree of abstraction of philosophical notions on a meta-level. This is a level on which both the technology and methodology are shaped that will detect, establish, and formulate the architectural problem. In addition to enabling the production of specific connections and structure the architectural system of thinking, the philosophical notions become 'intensities' in architectural processes. That is to say, aside from the change in thought perspective, they allow for the movement and dynamic with the idea of possibility of control of space and time. The genesis of architectural concepts is followed by the establishment of a complex set of relations: from projecting/designing subject-object positions to a whole network of designed, contextual, symbolic, spatial and temporal relations. In order for the entire process to be controlled, the use of philosophical notions as blocks for generating a stable architectural linguistic structure is their basic use in architecture. A set of notions as well as the distinction of a particular notion often conditions and establishes direct terminological thematisations through the design process - conspicuous in the aesthetic of the project. This is similar 
to Tschumi's notions of 'event' or 'movement', or else Nouvel's thematisations of notions of 'dematerialisation' or 'illusion'. In that sense, projecting a diagram or network of notions is a process that follows the creation of an architectural concept or theory, but also design processes and the overall processes or the architectural project.

The choice of philosophical notions for the analytical structuring of the methodology of an architectural project is also a question of stability of the method of the process itself, while conceptualisation demands destabilisation, decomposition, or deconstruction of both the system and its notions. The creation of architecture always demands an exit beyond its material context into a deeper logic of production of reality from which potentially emerges even the relation that can be described with words as 'the feel' of a text. This means that an architect will use the word and text to enable the idea thematisation within and beyond the architectural project. Reading and drawing with notions becomes the motion (movement) towards the problem and its reality, or else simply a way for the notion to appear as an idea that will be thematised by the project. In that case, the notion remains closely tied to the image or drawing that follows it. Analogies and the parallelism of the notion and drawing begin to build an unusual form, integrated drawing and notion. And in the attempt to achieve the purpose of the architectural process, they begin to build authentic architectural representations. For example, in the theoretical project, The Manhattan Transcripts, Tschumi used the architectural interpretation of reality with plans, sequences, and diagrams to simultaneously introduce the 'notions', in order to emphasise the very purpose of the transcript..$^{30}$ Therefore, he represents the complex relations between space and its use, the set and script, type and programme, objects and events, through a sequence of drawings and notions. This method allows for the traditional architectural elements (drawing) to be criticised and verified by words, only to merge with them into unified meaning. The notion and drawing in architecture indicate that there is no disjunction between words and architectural objects, much as there is no disjunction between concepts and their use - in the way Wittgenstein has shown. ${ }^{31}$

\section{THE SPHERE OF DREAMS}

Deleuze constructed the plane of immanence as an abstract machine or consistent landscape of concepts, wherein “(...$)$ concepts are the infinite speeds of finite movements that, in each case, pass only through their own components." 32 The architectural character of Deleuze's plans, the plane of immanence, composition and reference, including the whole spectrum of projection (of horizontal and vertical cross sections), are models for interpretation of both 
architectural theory and practice. Aside from that, actualising the virtual, or the idea that in 'chaos' there could very well be structure and order. But also, when it comes to technical changes in interpretation of space and time, dimension and speed, Deleuze's theories offer endless conceptual and aesthetic, intuitive and epistemological architectural potential. Despite all its theoretical strongholds, the contemporaneity of projection of the philosophical-architectural relation is refracted through the question of how to directly engage the philosophical concept? That is, what are the possible reflections of a particular philosophical concept in architecture?

Using elements and the logic of space, as metaphor and model, Peter Sloterdijk developed his theory of spheres: "trilogy on spheres" (Plurale Sphärologie). ${ }^{33}$ He used text to materialise the "architecture of foam" in order to construct space as a crucial anthropological category. All the philosophical questions of spherology, what space could be, what we expect space to be, what we can offer as future space, are also fundamental architectural questions. In the theory of spheres, the outside as the product of the inside and people as the effect of space they create, delineate the contemporary architectural dilemma: where is the limit of architectural space. Philosophical concepts are projected through processes of 'aesthetisation' of cross sections of the interior and exterior, the ideologisation of cosmological questions of time and space, but also the thematisation of fundamentally intimate relationship of space and the human are all explicit interpretation of spatial-temporal relations and forms of reading space, and as such are directly utilisable in the methodology of the architectural project. The construction of "protective islands" as forms of border spaces for the satisfaction of the human need to 'immunise' existence, ${ }^{34}$ paradigmatically offers specific criticism about the architectural constitution of (the ideal) object. Further, the poetry of space as well as shape offered by the various spheres and micro-spherological phenomena, become the topic of architectural design. Thus, these 'spheres', bubbles, globes or foam can be introduced into the 'sphere of architecture', as complete architectural models due to their literal spatial description, their capacity to adopt geometries and constructions, but also the aesthetic of architectural space or particular object. Even more significantly, the morphological theory of the spheres leads in fact directly to the architectural question of projection. Each form of created space has its projection, meaning that the question of projection refers directly to the process of spatial creation. The trilogy of spheres encompasses the architectural problem of not only the projective and anthropological dimension, but many questions from geometry, generic conceptions, morphogenesis, transparency and form, all the way to the literal construction of forms and space. The problem of the universal and the cosmological, the question of multiplication, like bubbles, 
or else questions of the universal, such as drawing on slated globes point to Sloderdijk's theory providing a clear technology and method of application in architectural conceptualisation, as well as direct phenomenological projections. Latour's networks ${ }^{35}$ - at first glance similar, yet entirely different - can also be used as architectural tools. The conceptual aspect of the network offered by Latour are manifold, from metaphors of sublime "fragility"36 of the network (des réseaux) or the idea of empty space which the network comprises, to the complex relations of proximity and distance, node and line, digital and analog. Nearly infinite models offered by this 'network' system, that is, the capacity to deconstruct the distinction of proximity-distance by a change of scale, of changing the inner-outer relations by control of dimension, and to relativise time by connecting unconnected elements - all makes the 'networks' entirely utilisable as architectural diagrams.

Between the architectural diagram and model, the philosophical concept of the rhizome ${ }^{37}$ projected by Deleuze and Guattari introduces into architecture (but also philosophy!) entirely authentic, 'new' structures of thought. The six principles with which they described the particularity of the rhizome are explicitly usable as a formal principle in the methodology of architectural project. ${ }^{38}$ I would like to distinguish between the principles and all the other characteristics of the rhizome into two groups. The first refers directly to the morphology, the structure, the shape and form. The second group refers to processes. The rhizome, a type of branching of the root expanding horizontally, with all its multiplied variations, reveals a clear spatial principle of expansion, but also the idea of mapping of territory and fundamental stabilizing of 'soil'. The identity of this structure or its nature that generates multiplicities, offers infinite possibilities of expansion, which is a nearly perfect expression of the architectural modelling of space. The geometric forming (in the full sense of contemporary geometries) of morphological, structural, certainly spatial theories, we convert into morphological configurations of architectural concepts, but also into specific forms of spatial realities. Real implications of this philosophical concept, systemic openness, de-centeredness, and resistance to hierarchy, influence the idea of openness of the architectural concept. Architecturally speaking, what is always constructed along with the processes of construction is the technology itself that reorganises both space and its creation. The expansion of territory by mapping it in a rhizomatic structure, and the possibility of broad 'grounding' undoubtedly becomes the critical apparatus of physical dimensions of space, growing into theories of infinite 'openness' in which contemporary architects could place new platforms, generic structures for the development of new concepts of architectural projection. 
Thus, the architectural engagement of the philosophical concept has myriad roles. In addition to direct theoretical application, paradoxically, their formal aesthetic potential becomes significant just like the question of strategy of occupying space (through a horizontally rhizomatic structure, cosmological Sloterdijk's spheres or networks that convert empty spaces into architectural diagrams). It is a matter of the creation of new territories, thought and space, a change in dimension and speeding up of time by exchange of concepts. Donald Schön suggested a theory of "displacement concepts" in which each new (architectural) concept appears on top an old one. ${ }^{39}$ This idea evokes ideas of background, which we also find in Deleuze's definition of environment. ${ }^{40}$ In the contemporary world of exhaustion through endless possibilities enabled by the precision of digital technology, the question arises how to create new concepts, how to actually maintain philosophy and architecture (as concept creation), and with this the creation of the world and reality. This problem is underscored by Stiegler, not only by asking what could be the new concepts, but the more important question of how technology will project the new concepts? Literally, what are the potentialities of creation of new concepts? ${ }^{41}$ Stiegler sees a resource for the possibility of creation of the new in the potential of "the dream." Perhaps this is why 'new' productions of architecture can be seen as a reflection of new techniques and methodologies for the creation of new concepts. Thus, the philosophical-architectural 'exchange' is no longer merely a question of exchange of concepts, but a problem of (common) techniques of the construction of 'the dream' in which the (architectural) concept would appear.

\section{REPETITION OF DIFFERENCE}

According to Wolff, to have a notion (Begriffe) of something means that we can think of it when we have a mental representation about it. ${ }^{42}$ The notion can be represented with an image or a drawing. ${ }^{43}$ This is the first important 'difference' we can make here in 'repeating the notion'. To be sure, not the notion, but repeating the notion as the representation with an architectural image or drawing. The difference is always defined as the particularity that appears as an excess compared to the established value. Therefore, the difference is what always appears as new in relation to the previous. Besides, the difference is always undetermined, its appearance anticipated from the unidentical. For this reason, the architectural engagement of the philosophical concept does not encompass the literal transposition or repetition of the conceptual content; rather, it includes the creation of unidentity, through changes in dimension and time. The architect must execute the transformation of the philosophical concept in order to reach the precision and clarity of their architectural concept. Philosophical concepts bring a kind of logical order, a consistency and stability 
to the architectural concept. Moreover, when they are directly architecturally engaged in the processes of projection of the architectural concept, they assume responsibility for a much greater complexity and dynamic. Therefore, not only do they create universal order, philosophical concepts and notions but allow for the creation of further and more detailed actions and processes. For the architect, the philosophical concept, apart from its critical role, enables further production of yet more differences and concepts, plans of immanence and architectural platforms. Rather than systematising and interpreting, they create strategies how to 'differentiate' and how to produce the new. In this way, the role in between the philosopher and architect becomes defined by the relation of the analogous (difference) and digital (repetition). All the already elaborated models and uses of philosophical concepts complementing one another, can be combined, although paradoxically, on their own, they never achieve the authentic architectural concept. Therefore, I suggest an activity of emancipation of difference, as the condition for the new creation of the "different," that is the authentic in architecture. This means that by repetition of various philosophical concepts one emancipates the difference that is not philosophical, and as such is subject to a further procedure of architectural repetition that produces specific architectural value. This is the new potential in architecture.

\section{CONCLUSION, OR WRITING AND DIFFERENCE (DRAWING AND DIFFERENCE)}

There are several more or less complex ways to approach the question from the title of this text. The first is with the original, Nietzsche's question, "Why I Write Such Good Books?” The second, with Derrida's 'quip', that is, question: "Why Peter Eisenman Writes Such Good Books?", as well as with Eisenman's response that Derrida translates into irony, or the many interpretations of Nietzsche's question. All the answers carry ideas of the specific relation of the architectural creation and philosophical thinking. Eisenman coined the phrase "The Architectural Philosophy" and paradoxically, by bringing these words together (architecture \& philosophy), attempted to create their distance. Still, above all, what is always present is the simple idea about the exchange of 'objects' from philosophy and architecture, as technique and method, as well as ideas about mutual criticism and inspiration in the processes of creation. Philosophical and architectural concepts are never identical. On the meta-level, philosophy deals with universal positions, whereas architecture concerns itself with projections of space and time. All contemporary problems of the world and reality, philosophy and architecture, essentially reduce to the question how to create new concepts. This includes current questions of techniques of production of entirely new concepts and occupying new territories, that 
is, new dimensions of space and new ideas of time. Philosophers 'delineate' the thinking of the universal, surpassing demonstrations of relations of space and time, all the while providing the basis for their interpretation, as capacity for further drawing. For this reason, while forever remaining autonomous, philosophy will as ever offer architecture the philosophical concept; architecture in return, the possibility of its projection, that is, the potential of its materiality in the architectural concept as 'detail' to become real. Thus, "The Architectural Philosophy," becomes analogous to Metaphilosophy, ${ }^{44}$ along with the particular philosophy of the architect, tied primarily to architectural creation, that is, the production of architectural concepts, becomes the basis for the construction of "the philosophy platform of the architect." My suggestion for a philosophical platform for the architect is the idea in which the value of differences of philosophical concepts can become that which will in the new architectural repetition produce the authentic drawing of architectural difference. This is the new architectural concept. 1994).

Ibid., 2.

“Et nous n'avions pas cessé de le faire précédemment, et nous avions déjà la réponse qui n'a pas varié: la philosophieestl'art de former, d'inventer, de fabriquer des concepts." Gilles Deleuze and Félix Guattari Qu'est- ce que la philosophie (Paris: Les éditions de minuit, 1991), 8.

Gilles Deluze, Difference and Repetition (New York: Columbia University Press, 1991).

Predrag Krstić, Subjekt protiv subjektivnosti: Adorno i filozofija subjekta [Subject against Subjectivity: Adorno and the Philosophy of the Subject] (Belgrade: IFDT, 2007), 10.

Michel Foucault, "What Is an Author?" in The Foucault Reader, ed. Paul Rabinow (New York: Pantheon Books, 1994), 101-120.

The term subjectivity (subjectivité in French) makes the 'subject-object' distinction as subjectivity against objectivity (or subjectivity:objectivity). 
"In sharp contrast to the usual ideal of science, the objectivity of dialectical cognition needs not less subjectivity, but more.” Theodor Adorno, Negative Dialectics (London, New York: Routledge, 2004), 40.

Jean Baudrillard, Why Hasn't Everythng Already Disappeared? (London, New York: Calcutta, 2007), 10 .

Ibid., 10-12.

Petar Bojanić, Vladan Djokić, eds., Peter Eisenman: In Dialogue with Architects and Philosophers (Milano: Mimesis International, 2017), 128.

Ibid., 119.

Ibid., 164. ["M. C.: Literal figuration means what you see is what you get. Transfiguration means that what you get is particular to what you see."]

John Rajchman, Constructions (Cambridge, Massachusetts, London, England: MIT Press, 1997), 61.

Charles Jenks calls these changes "self-reinvention." Charles Jenks, "Le Corbusier and the Revenge of the Book," in Le Corbusier \& The Architecture of Reinvention, C. Jencks et al. (London: AA Publications, 2003).

Le Corbusier, Le Poème de l'Angle Droit, (Paris: Éditions Tériade, 1955). The Poem of the Right Angle is a series of 19 photographs and texts by Corbusier, made between 1947 and 1953.

Jörg H. Gleiter, "Peter Eisenman, or How to Eliminate What One Becomes", SAJ, Volume 6. No. 03, ISSUES?, 03 (2014): 228-237.

Roland Barthes, "The Death of the Author," in Roland Barthes, Image, Music, Text, ed. Stephen Heath (London: Fontana Press, 1977), 142-149. Barthes' text preceded Foucault's.

Michel Foucault, "What is Critique?" in The Politics of Truth, ed. Sylvère Lotringer (Los Angeles: Semiotext(e), 2007), 41-83.

On "meta-project," cf. SnežanaVesnić, "What Is an Architectural Concept? The "Concept" of Deleuze and "Project" of Eisenman." Philosophy and Society, 4 (2017): 1122-1136.

According to Foucault, the trace of the writer is to be found only in the particularity of their absence.

Baudrillard, Jean and Jean Nouvel, The Singular Objects of Architecture (Minneapolis: University of Minnesota Press, 2002), 6.

Ibid.

Peter Sloterdijk, Derrida, an Egyptian: On the Problem of the Jewish Pyramid (Cambridge: Polity Press, 2009), 13.

Ibid.

Peter Brunette, David Willis, eds. "The Spatial Arts: an Interview with Jacques Derrida," in Deconstruction and the Visual Arts: Media Architecture (Cambridge: Cambridge University Press, 1994), 20.

Peter Eisenman, Inside Out: Selected Writings, 1963-1988 (New Haven, London: Yale University Press, 2004), 222-224.

Jacques Derrida, "Why Peter Eisenman Writes Such Good Books," in Chora L Works: Jacques Derrida and Peter Eisenman, Jacques Derrida and Peter Eisenman (New York: The Monacelli Press, 1997), 97.

Peter Brunette, David Willis, ed. "The Spatial Arts: an Interview with Jacques Derrida," in Deconstruction and the Visual Arts: Media Architecture (Cambridge: Cambridge University Press, 1994), 20.

Bernard Tschumi, The Manhattan Transcripts (London: Wiley, 1995).

Ludwig Wittgenstein, Philosophical Investigations (Oxford: Blackwell Publishers, 1986), 171-174. 
Gilles Deleuze and Felix Guattari, What Is Philosophy? (New York: Columbia University Press, 1994), 36

Peter Sloterdijk, Sphären. Mikrosphärologie - Band I: Blasen (Berlin: Suhrkamp Verlag, 1998). Peter Sloterdijk, Sphären. Makrosphärologie - Band II: Globen (Berlin: Suhrkamp Verlag, 1999). Peter Sloterdijk, Sphären. PluraleSphärologie - Band III: Schäume (Berlin: Suhrkamp Verlag, 2004).

Peter Sloterdijk, "Talking to Myself about the Poetics of Space," in Harvard Design Magazine, (Sustainability) + Pleasure, Vol. I: Culture and Architecture, No. 30, S/S 2009.

According to Latour, his network theory and Sloterdijk's theory of spheres are two ways of representing "sets of concepts" that could explain the world, as well as the conditions of the world that could become suitable for life ["Peter et moi avons proposé d'introduire, chacun à sa façon, deux ensembles de concepts, l'un venant des sphères et l'autre des réseaux.']. Bruno Latour, "Spheres and Networks. Two Ways to Reinterpret Globalization." Harvard Design Magazine, Spring/Summer, No. 30 (2009): 138-144.

Bruno Latour, "Networks, Societies, Spheres: Reflections of an Actor-network Theorist." International Journal of Communication 5 (2011): 796-810.

Cf. Gilles Deleuze, Félix Guattari, Mille Plateaux. Capitalisme et Schizophrénie (Paris: Les Éditions De Minuit, 1980).

Ibid., 3-8.

Donald Schön, Displacement of Concepts (London, New York: Routledge, 2001).

The word 'environment' here is the English rendering of the French milieu, which also includes the meanings of 'middle' and 'medium'. Deleuze and Guattari give it a specific interpretation combining all three meanings.

Bernard Stiegler, Technics and Time, 1: The Fault of Epimetheus (Stanford: Stanford University Press, 1998), 145.

On the difference between notion and concept, see: SnežanaVesnić, "What Is an Architectural Concept? The "Concept" of Deleuze and "Project" of Eisenman." Philosophy and Society, 4 (2017): 1122-1136.

Christian Wolff, Logica Tedesca. Testo tedesco a fronte (Milan: Bompiani, 2011), 123. 
Adorno, Theodor. Negative Dialectics. London and New York: Routledge, 2004.

Barthes, Roland. "The Death of the Author." In Roland Barthes, Image, Music, Text, ed. Stephen Heath. London: Fontana Press, 1977.

Baudrillard, Jean and Jean Nouvel. The Singular Objects of Architecture. Minneapolis: University of Minnesota Press, 2002.

Brunette, Peter and David Willis, ed. "The Spatial Arts: an Interview with Jacques Derrida." In Deconstruction and the Visual Arts: Media Architecture, 9-32. Cambridge: Cambridge University Press, 1994.

Deleuze, Gilles, and Felix Guattari. What Is Philosophy?. New York: Columbia University Press, 1994.

Deleuze, Gilles. Difference and Repetition. New York: Columbia University Press, 1994.

Deleuze, Gilles, Félix Guattari, Mille Plateaux. Capitalisme Et Schizophrénie. Paris: Les Éditions De Minuit, 1980.

Djokić, Vladan and Petar Bojanić, eds. Peter Eisenman. In Dialogue with Architects and Philosophers. Milan: Mimesis International, 2017.

Eisenman, Peter. Inside Out Selected Writings 1963-1988. New Haven and London: Yale University Press, 2004.

Foucault, Michel. "What Is an Author?" In The Foucault Reader, ed. P. Rabinow. New York: Pantheon Books, 1994.

Foucault, Michel. "What is Critique?" In The Politics of Truth, ed. S. Lotringer. Los Angeles: Semiotext(e), 2007.

Gleiter, Jörg H. "Peter Eisenman, or How to Eliminate What One Becomes", SAJ, Volume 6. No. 03, ISSUES?, 03 (2014): 228-237.

Jenks, Charles. "Le Corbusier and the Reinvenge of the Book." In Le Corbusier \& The Architecture of Reinvention, Charles Jencks at all. London: AA Publications, 2003.

Крстић, Предраг. Субјект против субјективности: Адорно и филозофија субјекта [Subject against Subjectivity: Adorno and the Philosophy of the Subject]. Belgrade: IFDT, 2007.

Latour, Bruno. "Spheres and Networks. Two Ways to Reinterpret Globalization.” Harvard Design Magazine, Spring/Summer, No. 30 (2009): 138-144.

Latour, Bruno. "Networks, Societies, Spheres: Reflections of an Actor-network Theorist." International Journal of Communication 5 (2011): 796-810.

Le Corbusier, Le Poème de l'Angle Droit [The Right-Angle Poem]. Paris: Éditions Tériade, 1955.

Nietzsche, Friedrich. Ecce Homo: How to Become What You Are. Oxford: Oxford University Press, 2009.

Schön, Donald. Displacement of Concepts. London, New York: Routledge, 2001.

Stiegler, Bernard. Technics and Time 1: The Fault of Epimetheus. Stanford: Stanford University Press, 1998.

Sloterdijk, Peter. Derrida, an Egyptian: On the Problem of the Jewish Pyramid. Cambridge: Polity Press, 2009.

Sloterdijk, Peter. "Talking to Myself about the Poetics of Space." In Harvard Design Magazine, (Sustainability) + Pleasure, Vol. I: Culture and Architecture, No. 30, S/S, 2009.

Tschumi, Bernard. The Manhattan Transcripts. London: Wiley, 1995.

Vesnić, Snežana. "What Is an Architectural Concept? The "Concept" of Deleuze and "Project" of Eisenman.” Philosophy and Society, 4 (2017): 1122-1136.

Williamson, Timothy. The Philosophy of Philosophy. Oxford: Wiley-Blackwell, 2007.

Wittgenstein, Ludwig. Philosophical Investigations. Oxford: Blackwell Publishers, 1986.

Wolff, Christian. Logica Tedesca. Testo tedesco a Fronte. Milan: Bompiani, 2011. 


\section{FILOZOFSKA PLATFORMA ARHITEKTE.}

\section{ZAŠTO FILOZOFI CRTAJU TAKO DOBRE CRTEŽE? \\ Snežana Vesnić}

Teorijska tumačenja i praktični pokušaji instrumentalizacije veze i razmene između filozofije i arhitekture uglavnom su usmereni na pitanja jezika ili na institucionalizaciju discipline arhitekture. U ovom tekstu predlažem jedan drugačiji pristup angažovanja filozofije u arhitekturi: istovremenom upotrebom u metodologiji arhitektonskog projekta i konstituisanju filozofije arhitekte, kao integralni deo potpunih arhitektonskih procesa, pri čemu filozofija zadržava svu svoju izvornu autentičnost. Moj pristup je dvostruk: objašnjava samu metodologiju pristupa i iscrtava svoj okvir, ali i postavlja pitanje "šta je filozofska platforma arhitekte". U tu svrhu ću pokušati da izgradim tri modela: 1) prvi model delimično zalazi u polja fikcije i iluzije, i to je model u kome arhitekta preuzima ulogu (poziciju) filozofa, 2) drugi model je ahitektonsko angažovanje filozofskih pojmova i, 3) treći, upotreba filozofskih koncepata u kreiranju arhitektonskih koncepata. Naspram sva tri, predložiću aktivnost "ponavljanja razlike" kao mogućnost stvaranja autentičnog arhitektonskog koncepta.

KLJUČNE REČI: KONCEPT, ARHITEKTURA, RAZLIKA, FILOZOFIJA, PLATFORMA

\section{ZAMIŠLJENI GRAD: REPREZENTACIJA JUGOSLOVENSTVA U FILMU ČUDNA DEVOJKA (1962) JOVANA ŽIVANOVIĆA}

\section{Tatjana Karabegović}

Interpretacija gradova na filmu u društvenom (filmskom) kontekstu nije mimesis, već model u proizvodnji značenja koji funkcioniše na osnovu znakova organizovanih u vizuelni jezik. Kako su značenja proizvedena unutar kulture i istorije, gradovi na filmu su proizvodi društvenog (politički motivisanog) znanja, jezičke strukture, otvoreni tekstovi u društvenom i kulturnom polju koji, posredstvom moći, tj. produktivnom mrežom koja prožima društvo, zastupaju određeni sistem vrednosti i, kao jedan u sistemu političkih, kulturalnih, naučnih, umetničkih tekstova, režima iskazivosti društvenih identiteta, formiraju arheologiju znanja. Tumačenje interpretacija gradova na filmu sa stanovišta studija kulture pokazuje da konfiguracije gradova (moderne arhitekture) van njihovih fenomenologija nisu konfrontirane uobičajenim postavkama binarnih opozicija na kojima je većina njihovih interpretativnih tradicija i zasnovana, već da služe ostvarenju određenih kulturnih uloga i da su otvorena semiotička polja kojima jedna zajednica proizvodi poželjnu (pokretnu) sliku o sebi.

KLJUČNE REČI: GRAD, MODERNA ARHITEKTURA, URBANA KULTURA, REPREZENTACIJA, FILM, IDEOLOGIJA, IDENTITET, JUGOSLOVENSTVO

\section{HIBRIDNOST U I IZVAN ARHITEKTURE: LIMINALNO STANJE \\ Ivana Jevremović}

Fokus istraživanja je na hibridima i hibridnosti, sa akcentom na njihovom liminalnom karakteru i programskoj i formalnoj ne-konačnosti. Ovaj rad daje uvid u istraživanje sprovedeno za potrebe izrade doktorske disertacije i predstavlja granični teorijski okvir za diskusiju i definisanje hibridnosti u arhitektonskoj teorij i praksi. Hibridnost se raspravlja kroz društvno-humanistički diskurs i arhitektonsku teoriju u kontekstu kulture i arhitekture. Rad predstavlja hibrid kao stanje koje se može posmatrati kroz koncept liminalnosti i konstantne promene nasuprot konačnosti bilo koje vrste. U tom kontekstu, cilj rada je da se hibridnost problematizuje i pozicionira u savremenom arhitektonskom diskursu, a na osnovu etimoloških i konotativnih odlika ustanovljenih kroz dodirne discipline iz oblasti društveno-humanističkih nauka. 